\title{
Climate Change and the Economic Vulnerability of Household in Niger Delta Region
}

\author{
Eronmhonsele, Job Imharobere $^{1^{*}}$, Erhabor Igbinosa Norris Ph. ${ }^{2}$ \\ ${ }^{1}$ Centre for Population and Environmental Development (CPED) \\ ${ }^{2}$ Department of Health Safety and Environmental Education, University of Benin, Nigeria \&Mentee, Centre for \\ Population and Environmental Development (CPED)
}

*Corresponding Author: Eronmhonsele, Job Imharobere, Centre for Population and Environmental Development (CPED), Nigeria

\begin{abstract}
The purpose of the study is to assess the impact of climate change on the economic vulnerability of households in Niger Delta region.A cross-sectional descriptive survey design was adopted for the study. Literature review was done through secondary data collection. Field surveys were carried out in ten LGAs sampled from the three ecological zones as follows: Mangrove Swamp (Warri South, Isoko South, Burutu and Patani); Freshwater Swamp (Ethiope East, Ughelli South, and Sapele) and Lowland Forest (Ika South, Anioma North and Ndokwa East). Quantitative data collection entailed the administration of between 400 and 450 household questionnaires in each selected LGA; a total of about 4000 successfully completed household questionnaires were retrieved cleaned up and used for the quantitative data analysis. The data were analysed using percentages. It was discovered in the study that most of the respondents live in precarious conditions and are intrinsically vulnerable to any shocks that affect their agricultural systems. Agriculture is their mainstay for livelihoods, serving both as the primary source of household food and principal means of income generation. Consequently, the fate of these respondents is closely interwoven with that of agriculture. Niger Delta farmers and fishermen are particularly vulnerable to any reductions in crop productivity for a variety of reasons. Thus it was recommended that future researches are needed to find effective advising strategies that can help farmers and fisher folk access information on, and capital to invest in, specific adaptation strategies.
\end{abstract}

Key Words: Climate change, vulnerability, Niger delta, agriculture, economic

\section{BACKGRound OF The STUdY}

Recently there has been a flurry of activities regarding climate change in the Niger Delta region of Nigeria. Some of these have been by non-governmental organizations (NGOs) and civil society groups while others are more academic and policy-oriented. In terms of research, it has been estimated that over 70 million cubic meters daily, amounting to about 70 million tonnes of carbon dioxide are flared off during oil and gas exploration and production activities in the Niger Delta region (UNDP/World Bank 2004). Approximately 75 percent of total gas production in Nigeria is flared. It has been further estimated that Nigeria accounts for about $17.2 \%$ of global gas flaring. As a result, more gas is flared in Nigeria's Niger Delta than anywhere in the world. Flaring in Nigeria contributes a measurable percentage of the world's total emissions of greenhouse gases (GHGs) and is probably the greatest contributor of GHGs in the Niger Delta region. Due to the low efficiency of many of the flares much of the gas is released as methane (which has a high warming potential), rather than carbon dioxide. At the same time, the low-lying Niger Delta is particularly vulnerable to the potential effects of sea levels rising.

Climate change in the Niger Delta contributes to sea level rise, affects rainfall pattern, emergence of diseases and pests, crop and animal production, fisheries, biodiversity, frequency and regularity of floods. This being the case, communities in the Niger Delta would seem to be especially at risk with serious consequences for property, livelihoods and the environment (Ugochukwu\& Ethel, 2008). The few other studies of climate change in the Niger Delta region have tended to be orientated to social aspects and food security. For example, Ijeoma (2012) examined people's perceptions and attitudes towards gas flaring. This study concludes that most residents appear to be resigned to the continued presence of gas flaring activities in the community. The study, however, raised several questions on 
modelling perception and attitudes toward environmental problems in areas where political tension and economic adversity are prevalent. A related study explored the spatial variability effects of gas flaring on the growth and development of cassava (Manihotesculenta), waterleaf (Talinumtriangulare), and pepper (Piper spp.) crops commonly cultivated in the Niger Delta (Dung et al. 2008). Findings of this study indicate that cassava yields were higher at location further away from gas flare while starch and ascorbic acid tended to decrease when cassava plant is grown close to gas flare. Curiously, however, the study also found that the waterleaf plant appeared to thrive better around the gas flare point (Dung et al. 2008).

Some Niger Delta-based NGOs such as Community Research and Development Centre (CREDC) and Environmental Rights Action (ERA) have also been active in trying to create awareness about impacts of gas flaring and its linkages with climate change and poverty in the region (Uyigue\&Agho 2007, 2009). Another National Non-governmental Organisation, Building Nigeria's Response to Climate Change (BNRCC) in collaboration with Nigeria Environmental Study/Action Team (NEST) have carried out some of their studies in parts of the Niger Delta region but key policy promotion activities have not taken place. Most of the recent studies in the Niger Delta have addressed issues of environmental degradation and vulnerability and mitigation of climate change impacts (Akinro et al, 2008), coastal management and adaptation to climate change (Etuonovbe, 2008), climate change, poverty and women's socio-economic challenges. The need for building institutional and professional capacity of urban and regional planners in the face of the climate challenge has also been advocated (Olujimi, 2007).

The available literature on climate change in Nigeria in the context of the Niger Delta region is characterized by some challenges. In the first place, research quality in Nigeria including climate change research during the last thirty years has been impacted by the poor funding of higher education in the country. Local research on climate change issues has been generally weak and limited. Most of the limited research activities carried in the country is funded by international agencies and foundations and these focused mainly on socio-economic issues largely as a result of the socioeconomic problems facing the country since the early 1980s. Even then the limited research activities on climate change were carried out at the national level with little attention paid to specifically to the Niger Delta region, especially during the period when conflict and violence characterized the region. Secondly, due to the poor funding of research and the inability of researchers in Nigeria to effectively compete for grants from international donors, most of the studies are small scale, focusing on isolated issues relating to climate change mainly focusing on environmental degradation. Thirdly, an examination of the available literature indicates that in the context of the Niger Delta region and indeed other parts of Nigeria, the understanding of vulnerability to climate change and the strategies and pathways for adaptation are currently enveloped in high uncertainties because of inadequate scientific data in many respects.

Vulnerability refers to the level of exposure to injury, damage or harm. Vulnerability to climate change is the degree to which geophysical, biological and socio-economic systems are susceptible to, and unable to cope with, adverse impacts of climate change (IPCC, 2007). The IPCC-CZMS (1992) defines vulnerability of coastal communities as the degree to which they are incapable of coping with the impact of climate change and accelerated sea level rise. The literature is replete with studies on vulnerability assessments but there is no concise and generally accepted definition of vulnerability, since the issue of vulnerability transcends biophysical, socio-economic, political and environmental boundaries. In this region, farming is the major economic activity of Delta State as in other NDDC States and indeed Nigeria. Farming activities employ over 60 per cent of the working population in the state. The farming systems in Delta State involve principally the traditional peasant subsistence/crop farming method, with land and labour being the principal inputs of production. It is further characterised by small-sized farm holdings of less than one hectare per household. Commonly, very simple traditional farming tools including cutlasses, hoes and axes are employed in single and mixed crop farming. Other economic activities are fishing, livestock farming, fish processing and forest resources and activities. These economic activities are affected by climate change. Thusthis study investigated the impact of climate change on the economic vulnerability of household in Niger Delta region.

\subsection{Purpose of the study}

The purpose of the study is to assess the impact of climate change on the economic vulnerability of 
households in Niger Delta region.

\section{Material(S) And Method}

A cross-sectional descriptive survey design was adopted for the study. Literature review was done through secondary data collection. Field surveys were carried out in ten LGAs sampled from the three ecological zones as follows: Mangrove Swamp (Warri South, Isoko South, Burutu and Patani); Freshwater Swamp (Ethiope East, Ughelli South, and Sapele) and Lowland Forest (Ika South, Anioma North and Ndokwa East). Administratively, the LGAs targeted in Mangrove Swamp ecological zone are in Delta South Senatorial District. Those in Freshwater Swamp are in Delta Central Senatorial District. Finally, those in Lowland Forest zone are in Delta North Senatorial District. Quantitative data collection entailed the administration of between 400 and 450 household questionnaires in each selected LGA; a total of about 4000 successfully completed household questionnaires were retrieved cleaned up and used for the quantitative data analysis. An average of between 1,250 and 1,500 household questionnaires were used in the analysis in each of the three ecological zones. Qualitative data collection entailed the conduct of key informant interviews and focused group discussions amongst mainly community-based stakeholders; A total of 107 key informants, with at least ten identified in each LGA were interviewed in the three ecological zones. Also three categories of focus group discussions were organised in each target LGA comprising "all males", "all females" and a mix of "males and females", respectively. Making a total of 30 FGDs conducted in the three ecological zones.

The data were analysed using percentages. Qualitative data from interviews, focus group discussions and observations were transcribed and used to elaborate on the statistical results.

\section{RESULT}

Many studies report that agriculture is one sector that is very vulnerable to climate change (Berry et al., 2006, Priya, 2010 and Sehgal et al, 2013). For this reason, the economic factor that can make households vulnerable to climate change impact is the extent of households' dependence on agriculture. The extent of dependence is measured by number of household members in agriculture as well as offering services as hired agricultural labour.

Table1. Percentage Distribution of Respondents according to Main Occupation

\begin{tabular}{|l|l|l|l|l|}
\hline Ecological Zones & $\begin{array}{l}\text { Farming and other } \\
\text { agricultural } \\
\text { activities }\end{array}$ & Trading & Public Sector & $\begin{array}{l}\text { Private } \\
\text { including } \\
\text { quarrying }\end{array}$ \\
\hline Mangrove Swamp & 46.9 & 25.0 & 13.2 & 14.9 \\
Freshwater Swamp & 81.1 & 12.0 & 3.7 & 3.2 \\
Lowland Rainforest & 51.9 & 28.4 & 7.8 & 11.9 \\
\hline
\end{tabular}

The results of the survey as presented table one above indicate that a high percentage of the respondents in the three ecological zones are engaged in agricultural production. The implication of this situation is that most of the households in the three ecological zones are extremely vulnerable to climate change. Respondents identified various factors that affect their household vulnerability to climate change as indicated in various Tables below.

Table2. Percentage Distribution of Respondents according to their assessment of non-availability of irrigation to the household vulnerability

\begin{tabular}{|l|l|l|l|}
\hline Ecological Zones & None & Low & High \\
\hline Mangrove Swamp & 49.8 & 25.7 & 24.4 \\
Freshwater Swamp & 29.6 & 39.3 & 31.1 \\
Lowland Rainforest & 83.1 & 14.1 & 2.8 \\
\hline
\end{tabular}

In situations of climate change and associated inadequate rainfall, irrigation becomes essential for sustainable agricultural activities. Table 2 shows that respondents identified the extent to which the non-availability of irrigation contribute to their economic vulnerability to climate change. The findings show that over 80 per cent of the respondents in the Lowland Rainforest ecological zone reported that the non-availability of irrigation had no effect on their household vulnerability to climate change apparently because they do not depend on irrigation for their farming activities. On the other hand significant proportions of the respondents in Mangrove and Freshwater ecological zones (24.4 and 31.1 per cent respectively) indicated that lack of irrigation affects their vulnerability because their 
agriculture partially depend on irrigation.

Table3. Percentage Distribution of Respondents according to their assessment of non-availability of water for livestock to the household vulnerability

\begin{tabular}{|l|l|l|l|}
\hline Ecological Zones & None & Low & High \\
\hline Mangrove Swamp & 50.1 & 25.5 & 24.4 \\
Freshwater Swamp & 49.2 & 38.5 & 12.3 \\
Lowland Rainforest & 78.8 & 16.9 & 4.3 \\
\hline
\end{tabular}

Similarly, water shortage can constitute challenges for livestock production activities and thereby expose farmers involved in livestock production to vulnerability. Table 3 indicates that the water shortage does not constitute a major challenge to a greater proportion of the farmers in the three ecological zones. It is only in the Mangrove Swamp ecological zone that about 24 per cent of the respondents indicated that non-availability of water is regarded as a major challenge. This can be explained by the fact that livestock production is not a major agricultural activity in the three ecological zones of Delta State.

Table4. Percentage Distribution of Respondents according to their assessment of excessive rainfall to the household vulnerability

\begin{tabular}{|l|l|l|l|}
\hline Ecological Zones & None & Low & High \\
\hline Mangrove Swamp & 4.7 & 9.9 & 85.4 \\
Freshwater Swamp & 3.0 & 21.4 & 75.6 \\
Lowland Rainforest & 2.3 & 15.4 & 82.3 \\
\hline
\end{tabular}

While rainfall is essential for agricultural production, excessive rainfall can be a major constraint to the activities of the farmers. Table 4 shows that the vast majority of the respondents (over 75 per cent) in the three ecological zones identified excessive rainfall as contributing remarkably to the vulnerability of their households. This indicates that excessive rainfall which has become a challenge associated with climate change is a major component of the economic vulnerability of the people of the Niger Delta region.

Table5. Percentage Distribution of Respondents according to their assessment of increase in drought to the household vulnerability

\begin{tabular}{|l|l|l|l|}
\hline Ecological Zones & None & Low & High \\
\hline Mangrove Swamp & 19.2 & 36.4 & 44.4 \\
Freshwater Swamp & 19.4 & 44.4 & 36.2 \\
Lowland Rainforest & 21.0 & 30.1 & 48.9 \\
\hline
\end{tabular}

On the other hand, lack of sufficient rainfall also constitutes a major challenge thereby resulting in economic vulnerability of the households in the three ecological zones of Delta state. Table 5 shows that a major proportion of the respondents regarded the phenomenon of increased drought in their communities as exposing their households to economic vulnerability.

Table6. Percentage Distribution of Respondents according to their assessment of the impact of increase in flooding to the household vulnerability

\begin{tabular}{|l|l|l|l|}
\hline Ecological Zones & None & Low & High \\
\hline Mangrove Swamp & 6.6 & 9.7 & 83.6 \\
Freshwater Swamp & 9.2 & 30.1 & 60.7 \\
Lowland Rainforest & 16.8 & 8.4 & 32.3 \\
\hline
\end{tabular}

Excessive rainfall obviously contributes to the occurrence of flooding which is a common feature of the Niger Delta region. Table 6 shows that the vast proportion of the respondents in the Mangrove Swamp and Freshwater Swamp regarded increased flooding as impacting on their economic activities. This is understandable because the two zones are nearer the ocean compared with the Lowland Rainforest ecological zone that is in the upland area.

Table7. Percentage Distribution of Respondents according to their assessment of the impact of low agricultural output to the household vulnerability

\begin{tabular}{|l|l|l|l|}
\hline Ecological Zones & None & Low & High \\
\hline Mangrove Swamp & 13.4 & 23.7 & 62.9 \\
Freshwater Swamp & 8.4 & 35.5 & 56.1 \\
Lowland Rainforest & 3.1 & 54.7 & 42.3 \\
\hline
\end{tabular}


Climate change obviously threatens agricultural output which in turn exposes agricultural households in the Niger Delta to economic vulnerability. Table 7 indicates that most of the respondents regard low agricultural output as a major challenge thereby exposing households to economic vulnerability. It shows that the vast proportion of the respondents in the three ecological zones regard the impact of low agricultural production as having low or high implications for the economic vulnerability of the households who depend on agriculture for their livelihood.

Table8. Percentage Distribution of Respondents according to their assessment of the impact of lack of farm labour to the household vulnerability

\begin{tabular}{|l|l|l|l|}
\hline Ecological Zones & None & Low & High \\
\hline Mangrove Swamp & 24.5 & 34.6 & 40.9 \\
Freshwater Swamp & 10.3 & 45.2 & 44.5 \\
Lowland Rainforest & 11.1 & 72.3 & 16.7 \\
\hline
\end{tabular}

Farm labour is a key component of increased agricultural production in the Niger Delta region. When farm labour becomes unavailable or inadequate, farmers are negatively affected in terms of their agricultural production. Low incomes from farm activities tend to propel farm labourers to migrate to urban centres thereby contributing to the shortage of farm labourers. Respondents as indicated in Table 8 confirm that the lack of farm labour had high impact on the vulnerability of households in the three ecological zones to climate change.

Table9. Percentage Distribution of Respondents according to their assessment of the impact of decreasing availability of arable land to the household vulnerability

\begin{tabular}{|l|l|l|l|}
\hline Ecological Zones & None & Low & High \\
\hline Mangrove Swamp & 13.1 & 22.0 & 64.8 \\
Freshwater Swamp & 11.7 & 36.3 & 52.0 \\
Lowland Rainforest & 9.5 & 60.0 & 30.5 \\
\hline
\end{tabular}

With the prevalence of various climate change indicators such as increased rainfall leading to flooding and increased temperature leading to drought, arable farm land begins to decline which in turn has negative impact on agricultural production. Table 9 indicates that the vast proportion of the respondents in the three ecological zones regard the decreasing availability of arable land has considerable impact on the vulnerability of households.

Table10. Percentage Distribution of Respondents according to their assessment of the impact of lack of food storage facilities to the household vulnerability

\begin{tabular}{|l|l|l|l|}
\hline Ecological Zones & None & Low & High \\
\hline Mangrove Swamp & 15.9 & 25.2 & 58.9 \\
Freshwater Swamp & 8.9 & 34.9 & 56.2 \\
Lowland Rainforest & 9.6 & 58.5 & 31.9 \\
\hline
\end{tabular}

Food storage facilities are essential components of increased and sustainable agricultural production in the various ecological zones in the Niger Delta region. Consequently when food storage facilities are not available increased and sustainable agricultural production becomes a problem. As indicated in Table 10, the vast proportion of the respondents in the three ecological zones reported that lack of food storage facilities has considerable impact on the economic vulnerability of households.

Table11. Percentage Distribution of Respondents according to their assessment of the impact of lack of transportation to the household vulnerability

\begin{tabular}{|l|l|l|l|}
\hline Ecological Zones & None & Low & High \\
\hline Mangrove Swamp & 16.1 & 16.2 & 67.8 \\
Freshwater Swamp & 15.4 & 52.2 & 32.3 \\
Lowland Rainforest & 13.5 & 48.0 & 38.4 \\
\hline
\end{tabular}

The transportation of agricultural outputs to markets is an essential component of the productive activities of farmers. When transportation is not available farmers suffer and face low incomes because they cannot market their products in urban markets where prices are higher. Table 11 confirms the challenge which the lack of transportation facilities imposes to the prosperity of farmers. The vast proportion of the respondents in the three ecological zones indicate that lack of transportation facilities exposes households to increased vulnerability. In the Mangrove Swamp ecological zone where transportation is much difficult a greater proportion (67.8 per cent) of the 
respondents indicated that lack of transportation is a major factor contributing to the vulnerability of households to climate change in the zone.

Table12. Percentage Distribution of Respondents according to their assessment of the impact of low income (poverty) to the household vulnerability

\begin{tabular}{|l|l|l|l|}
\hline Ecological Zones & None & Low & High \\
\hline Mangrove Swamp & 7.6 & 18.2 & 74.3 \\
Freshwater Swamp & 5.6 & 11.4 & 83.0 \\
Lowland Rainforest & 10.0 & 43.0 & 47.0 \\
\hline
\end{tabular}

There is no doubt that low income households are more negatively affected by climate change compared with those with higher incomes. This exposes low income households to increased vulnerability to climate change compared with higher income ones. The respondents confirm this fact because as indicated in Table 12 most of them reported that low income had considerable impact on the vulnerability of households in the three ecological zones.

Table13. Percentage Distribution of Respondents according to their assessment of the impact of conflicts and violence to the household vulnerability

\begin{tabular}{|l|l|l|l|}
\hline Ecological Zones & None & Low & High \\
\hline Mangrove Swamp & 28.9 & 29.1 & 42.0 \\
Freshwater Swamp & 30.4 & 33.1 & 36.5 \\
Lowland Rainforest & 44.0 & 38.3 & 17.8 \\
\hline
\end{tabular}

The Niger Delta region has been characterised by conflict and violence during the last thirty years with remarkable negative impact on the socio-economic life of the people in various communities. If climate change is combined with the occurrence of conflict and violence it generates considerable impact on the poor households in the region. Table 13 show that some of the respondents in the three ecological zones indicates that conflicts and violence have low or high impact on the vulnerability of their households to climate change effects.

Table14. Percentage Distribution of Respondents according to their assessment of the impact of lack of security to the household vulnerability

\begin{tabular}{|l|l|l|l|}
\hline Ecological Zones & None & Low & High \\
\hline Mangrove Swamp & 11.6 & 27.9 & 60.5 \\
Freshwater Swamp & 11.2 & 40.3 & 48.4 \\
Lowland Rainforest & 11.5 & 62.6 & 25.6 \\
\hline
\end{tabular}

In view of the conflict and violence challenges facing the Niger Delta region, the lack of adequate security poses major challenge to socio-economic activities in the communities of the region. Where such security is not provided it poses major challenges to the livelihood of the people in various communities. Table 14 shows the assessment of the respondents of the impact of lack of security on household vulnerability and it indicates that the vast majority of them believe that households in the three ecological zones are vulnerable to climate change because of the absence of adequate security.

Table15. Percentage Distribution of Respondents according to their assessment of the impact of pest attacks to the household vulnerability

\begin{tabular}{|l|l|l|l|}
\hline Ecological Zones & None & Low & High \\
\hline Mangrove Swamp & 17.3 & 27.9 & 60.5 \\
Freshwater Swamp & 12.2 & 36.6 & 51.2 \\
Lowland Rainforest & 11.4 & 45.8 & 42.8 \\
\hline
\end{tabular}

Pests and diseases pose a threat to food security because they can damage crops, thus reducing the availability and access to food, increasing the cost of food. Plant pests and diseases may also negatively affect the palatability of foods resulting in changes to the traditional food preferences of populations. Surveys of the relationship between pests and diseases and crop sustainability in several parts of Nigeria including the Niger Delta region indicate that the production of numerous crops has declined sharply as a result of major pest and disease outbreaks, and others are threatened with major decline because of a surge in virulence of an endemic pest or disease, the introduction of a virulent exotic pest or pathogen, or because a system of control used previously has collapsed. In other cases, crop sustainability has been preserved by vigorous farmer responses or by the intervention of national and international research institutions. Most pests and pathogens, however, remain within tolerable 
bounds most of the time, though this often requires the use of chemical or cultural controls, or the availability of adequate land to compensate for losses. As land availability declines, more strenuous management efforts may be needed to sustain productivity. Table 15 indicates that respondents in the three ecological zones of Delta State report that household vulnerability to climate change is greatly affected by pest attacks, which reduces agricultural productivity.

Table16. Percentage Distribution of Respondents according to their assessment of the impact of reptiles invasion to the household vulnerability

\begin{tabular}{|l|l|l|l|}
\hline Ecological Zones & None & Low & High \\
\hline Mangrove Swamp & 27.1 & 35.3 & 37.6 \\
Freshwater Swamp & 25.8 & 41.9 & 32.2 \\
Lowland Rainforest & 27.9 & 50.0 & 22.1 \\
\hline
\end{tabular}

Biological invasions are a growing problem in Niger Delta region as in other parts of Nigeria. Many alien species have been introduced for various reasons and through multiple pathways over the past few centuries. Invasive alien reptiles and amphibians (herpetofauna) are not yet a major problem in the country. However, escalating difficulties with invasive species suggest a high risk of increased problems in the future. There is a need to consider the potential threat of these species, and others still to be introduced, in line with practices in other countries where formal risk assessment policies are in place to separate potentially invasive species from those that are unlikely to be problematical. Table 16 shows that while a significant proportion of the respondents indicate that reptile invasion is not a serious problem a majority assert that it has negative impact on households in the various ecological zones. This suggests the need to consider policies to contain reptile invasion as part of climate change adaptation.

Table17. Percentage Distribution of Respondents according to their assessment of the impact of outbreak of diseases and epidemics to the household vulnerability

\begin{tabular}{|l|l|l|l|}
\hline Ecological Zones & None & Low & High \\
\hline Mangrove Swamp & 25.9 & 25.8 & 48.3 \\
Freshwater Swamp & 22.9 & 32.7 & 44.4 \\
Lowland Rainforest & 25.2 & 39.1 & 35.7 \\
\hline
\end{tabular}

Although public health has considerable experience with policies and measures to reduce health burdens of infectious diseases, some of which are climate-sensitive, current strategies, policies, and measures were not typically designed to account for alterations in the burdens of infectious disease associated with a changing climate.Assessing the potential infectious disease risks of climate change also requires considering the non-climatic factors that drive their incidence and distribution, including demographics, socioeconomic development, land use, urbanization, technology, and the political and health care context. Respondents are conscious of the impact of the outbreak of diseases and epidemics on household vulnerability to climate change. As shown in Table 17 most of them in the three ecological zones indicated as such.

Table18. Percentage Distribution of Respondents according to their assessment of the impact of water pollution to the household vulnerability

\begin{tabular}{|l|l|l|l|}
\hline Ecological Zones & None & Low & High \\
\hline Mangrove Swamp & 6.0 & 9.8 & 84.2 \\
Freshwater Swamp & 12.6 & 40.9 & 46.5 \\
Lowland Rainforest & 21.9 & 44.3 & 33.8 \\
\hline
\end{tabular}

Water is an essential resource for good health and wellbeing. Unfortunately, there are countless communities throughout Niger Delta region that do not have access to safe, clean water for drinking, cooking, and hygiene. Moreover, viruses, bacteria, parasites, and pollution contaminate freshwater sources resulting in 'water scarcity.' Water scarcity, coupled with poor sanitation practices, has resulted in an abundance of illnesses, diseases, and deaths. A lack of clean water also affects the people of the Niger Delta region in other ways. Many families have to travel further to gain access to clean drinking water. The women and girls in the family often take on this responsibility of having to carry heavy buckets of water back to their homes. Younger girls often have to drop out of school and miss out on getting an education to help their families. These journeys to collect water are also dangerous and sometimes result in physical or sexual abuse of girls and women. Table 18 confirms the challenge which water pollution poses to the vulnerability of households to climate change. The 
vast majority of respondents in the three ecological zones indicated that water pollution has impact on the vulnerability of the households to climate change.

Table19. Percentage Distribution of Respondents according to their assessment of the impact of loss of biodiversity to the household vulnerability

\begin{tabular}{|l|l|l|l|}
\hline Ecological Zones & None & Low & High \\
\hline Mangrove Swamp & 16.1 & 30.0 & 53.9 \\
Freshwater Swamp & 12.2 & 50.0 & 37.8 \\
Lowland Rainforest & 10.1 & 67.3 & 22.6 \\
\hline
\end{tabular}

The Niger Delta region is home to a rich and diverse animal, plant, and marine biodiversity that provide critical ecosystem services, driving the region's economy and serving as buffers to climate change. However, the region is experiencing a dramatic loss of biodiversity. Even more immediate are the ongoing threats to the region's biodiversity from natural habitat loss and degradation (especially from agricultural expansion), direct overexploitation of wildlife and fishery species (including from illegal hunting and trade), and the spread of certain non-native invasive species. This loss of biodiversity affects livelihoods, water supply, food security and lessens resilience to extreme events, particularly for people living in rural areas who are often the poorest. Table 19 shows that the vast proportion of the respondents in the three ecological zones confirm that the loss of biodiversity in the region contributes to the vulnerability of the households in various communities to the impact of climate change.

Table20. Percentage Distribution of Respondents according to their assessment of the impact of alteration of agricultural seasons to the household vulnerability

\begin{tabular}{|l|l|l|l|}
\hline Ecological Zones & None & Low & High \\
\hline Mangrove Swamp & 16.7 & 31.9 & 51.4 \\
Freshwater Swamp & 11.9 & 42.7 & 45.4 \\
Lowland Rainforest & 12.6 & 56.1 & 31.3 \\
\hline
\end{tabular}

Agriculture is an economic activity that is highly dependent upon weather and climate in order to produce the food and fiber necessary to sustain human life. Not surprisingly, agriculture is deemed to be an economic activity that is expected to be vulnerable to climate variability and change. It involves natural processes that frequently require fixed proportions of nutrients, temperatures, precipitation, and other conditions. Climate change affects agriculture in a number of ways; including through changes in average temperatures; rainfall and climate extremes with an important impact on soil erosion (i.e. floods, drought, etc): changes in pests and diseases, changes in atmospheric carbon dioxide, changes in the nutritional quality of some foods, changes in growing season, and changes in sea level. Crop yields show a strong correlation with temperature change and with the duration of heat or cold waves, and differ based on plant maturity stages during extreme weather events. Modified precipitation patterns will enhance water scarcity and associated drought stress for crops and alter irrigation water supplies. Table 20 shows that most respondents in the three ecological zones pointed out that alteration of agricultural seasons contribute to household economic vulnerability.

Table21. Percentage Distribution of Respondents according to their assessment of the impact of low fish cash to the household vulnerability

\begin{tabular}{|l|l|l|l|}
\hline Ecological Zones & None & Low & High \\
\hline Mangrove Swamp & 16.2 & 22.5 & 61.3 \\
Freshwater Swamp & 28.5 & 36.3 & 35.1 \\
Lowland Rainforest & 59.3 & 28.4 & 12.3 \\
\hline
\end{tabular}

Fisheries and aquaculture play important roles in providing food and income in Niger Delta communities, either as a stand-alone activity or in association with crop agriculture and livestock rearing. Thus fisheries and aquaculture make remarkable contribution to poverty reduction and food security in the region. When fish cash is low the implications for the vulnerability of farmers in the wetland areas of Niger Delta are obvious. Table 21 indicates that respondents are divided with respect to the degree of the impact of low fish cash on the vulnerability of households. Most of the respondents (over 61 per cent) in the Mangrove Swamp ecological zone where fish farming is the major economic activity reported that low fish farming contribute remarkably to household vulnerability. On the other hand, most of the respondents in the Lowland Rainforest zone where fish farming is limited indicated that low fish cash does not contribute remarkably to the vulnerability of the households. 


\section{DISCUSSION OF FINDINGS}

The findings of the survey show that most of the respondents live in precarious conditions and are intrinsically vulnerable to any shocks that affect their agricultural systems. As in most of rural Niger Delta region, the respondents live in rustic houses, lack electricity and running water, own few assets and rely on natural ecosystems for drinking water, firewood, wild foods and materials for household construction. Agriculture is their mainstay for livelihoods, serving both as the primary source of household food and principal means of income generation. Consequently, the fate of these respondents is closely interwoven with that of agriculture. Niger Delta farmers and fishermen are particularly vulnerable to any reductions in crop productivity for a variety of reasons. First, they cultivate very small parcels of land (less than 2 acres), dedicate most of their land to crop production for household consumption and obtain low crop yields, which are insufficient to meet household needs, let alone provide surplus for sale. In focal group discussions, farmers reported obtaining low yields. The low and declining yields basically reflect the limited use of inputs (fertilizers, pesticides, improved seed varieties, etc), the lack of animal traction, the use of low technology practices, the use of suboptimal land for production, the prevalence of slash and burn crop production, and land degradation - all of which have been identified as constraints to agricultural productivity not only in the Niger Delta region but in other parts of Africa.

The survey shows that majority of the households in all three ecological zones are chronically food insecure, which makes them extremely vulnerable to any climate or non-climatic shocks that further reduce agricultural production and food availability. Even in normal years, as revealed during interview and focus group discussion, three-quarters of the farming households lack sufficient food to feed their families and spend, on average, 3.8 months without sufficient food. Food pressure is most acute in the months immediately prior to the main harvest season. This seasonal pattern of food insecurity occurs across the Niger Delta region. The lack of sufficient food has significant livelihood impacts, including increased rates of malnutrition and child mortality. Another factor that increases the vulnerability of the households in the target communities is the remoteness of the villages and lack of adequate road infrastructure. In the rural communities across the three ecological zones, roads are in a poor state and unevenly distributed, with many villages lacking roads that connect them to other villages. Even the main roads are often accessible only during the dry season. The livelihood implications of this isolation are significant, as farmers and other primary producers have difficulties getting their products to markets as well as obtaining agricultural inputs; in addition, farmers generally have to pay higher prices for agricultural inputs in remote areas, reducing their profit margins.

A final set of factors that exacerbate household vulnerability in the target communities of Delta State is that most households lack access to formal safety nets to which they could turn in times of need. Most of the smallholder farmers remain outside a formal credit or banking system, lack capital and are unable to access credit or loans. There are no developed financial institutions located in them and instead farmers rely on informal support systems, borrowing money or food from family or friends. In addition, although there are numerous local NGOs working in the three regions, there is no formal extension service and less than $10 \%$ of the farmers currently receive any technical support. Farmers are further constrained by having limited access to agro-meteorological or market information, which could help inform farm management decisions, such as the choice of crops, planting dates and management strategies, and which could serve as early warning systems for floods, rainstorms and windstorms.

\section{CONCLUSION AND RECOMMENDATIONS}

This study has shown that farmers and fisher folks in the communities of Delta State are already feeling the effects of climate change. Exposure to floods and rainfall variability are only predicted to get worse as the impacts of climate change intensify. The consequences of these hazards on the wellbeing of the primary producers are severe, inducing intense episodes of food insecurity, which will force them to engage in erosive and unsustainable coping and adaptive strategies. Substantial improvements in the resilience of rural farmers and fisher folks are needed to address the current and increasing vulnerabilities of subsistence farmers and fisher folks in the communities of the region. The most effective way of reducing the vulnerability of farmers and fisher folks is through general adaptation strategies that focus on improving their overall well-being. This suggests the need for 
place-based studies of adaptive strategies to assess which specific projects will be most effective at reducing farmer or fisher folks' vulnerability under a wide variation of climate hazards.

Despite the promise of some specific adaptation measures, farmers and fisher folks emphasized their desire to remain autonomous in deciding what type of specific adaptation measures they choose to employ. They are looking for support in improving their general well-being so as to be in a better position to use their own resources to adapt to future changes. Although it is important to recognize the autonomy of farmers and fisher folks in their adaptation choices, it was also clear from discussion with them that they will need and are interested in receiving information and advice on potential adaptation strategies. Future researches are needed to find effective advising strategies that can help farmers and fisher folk access information on, and capital to invest in, specific adaptation strategies.

\section{ACKNOWLEDGEMENT}

This paper is an extract from an ongoing action research project on Climate Change in Delta State being implemented by Centre for Population and Environmental Development (CPED), Benin City, in collaboration with Intervention Council for Women in Africa (ICWA) and Delta state government through the Ministry of Environment. The project is being supported by the International Development Research Centre (IDRC), Canada. The authors are part of the project team, building the capacity of women and girls to deliver Climate Change adaptation and risk reduction initiatives in Delta state. The authors wish to acknowledge and thank the Centre for Population and Environmental Development (CPED), Benin City and the International Development Research Centre (IDRC), Canada for being part of the project team and also allowing us to use the data for this publication.

\section{REFERENCES}

[1] Akinro A.O. Opeyemi D.A. \&Ologunagba, I.B. (2008) "Climate Change and Environmental Degradation in the Niger Delta Region of Nigeria: Its Vulnerability, Impacts and Possible Mitigations" Journal of Applied Sciences Research 3(3):167-173 https://www.researchgate.net/ publication/336830096_Climate_ Change_and_Environmental_Degradation_in_the_Niger_Delta_Region_of_Nigeria_Its_Vulnerability_Im pacts_and_Possible_Mitigations

[2] Dung E, Bombom, L. \&Agusomu, T. (2008) "The effects of gas flaring on crops in the Niger Delta, Nigeria" GeoJournal, 73, (4). https://www.researchgate.net/publication/226770764

[3] Etuonovbe A. K (2008) "Sustaining Coastal Management / Adaptation of Climatic Change and Sea Level Rise in the Niger Delta Integrating Generations" FIG Working Week 2008 Stockholm, Sweden 14-19 June 2008 https://www.fig.net/resources/proceedings/fig_proceedings/fig2008/papers/ts03f/ts 03f_06_etuon ovbe_2753.pdf

[4] Ijeoma, S. (2012).Nigeria \& climate change adaptation. Nigeria: International Society of Sustainability Professionals (ISSP) Insight Publication.

[5] Olujimi J. (2007) 'Urbanisation of Peri-Urban Settlements: A Case Study of 'Aba-Oyo' in Akure, Nigeria" The Social Science 2 (1) 60-69. https://www.researchgate.net/publication/233855 640_Urbanisation_of_Peri-Urban_Settlements_A_Case_Study_of_\%27Aba-Oyo\%27_in_Akure_Nigeria

[6] Ugochukwu, C. N. C., and Ertel, J (2008) "Negative impacts of oil exploration on biodiversity management in the Niger De area of Nigeria," Impact Assessment and Project Appraisal, 26 (2).139-147, 2008.http://www.sciepub.com/reference/16419

[7] UNDP/World Bank (2004) "Nigeria Strategic GasPlan" Washington DC: Energy and Water Department The World Bank Group 1818 H Street, NW Washington, D.C. 20433, U.S.A., https://worldbank.org/curated/en/466291468780949357/pdf/ESM27910paper.pdf

[8] Uyigue, E. \&Agbo, M. (2009).Community Adaptation to Climate Change and other Environmental Changes in the Niger Delta Region ofSouthern Nigeria.Earth and Environmental Science.6(2009), 352041

[9] Uyigue E \& Matthew, A (2007) "Coping with Climate Change and Environmental Degradation in the Niger Delta of Southern Nigeria" Benin City: Community Research and Development Centre (CREDC) http://priceofoil.org/content/uploads/2007/06/07.06.11\%20-\%20Climate_Niger_Delta.pdf

\section{AUTHORS' BIOGRAPHY}

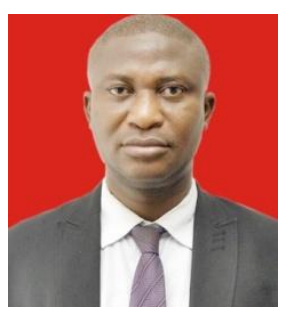

Job Imharobere Eronmhonsele, is the Deputy Executive Director (DED) of the Centre for Population and Environmental Development (CPED), Nigeria. He joined CPED as a research intern in 2008, rose to the position of Senior Programme Officer in 2012and was appointed DED in 2018. He holds Masters Degrees in Engineering and in Health Planning and Management. He has managed and implemented over 15 different action research and intervention projects in the areas of climate change, health systems strengthening, gender and 
development across Nigeria.He is an expert in communicating research evidence for policy influence through policy briefs and has published in reputable international journals.

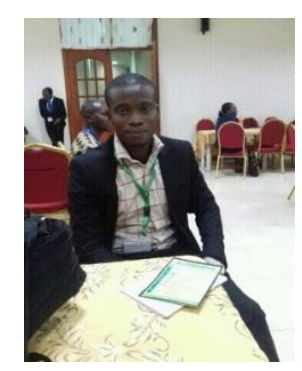

Erhabor Igbinosa Norris, is currently an Environmental Education lecturer in University of Benin, Nigeria. His area of expertise cut across climate change, environmental psychology, sustainable development, environmental education, environmental philosophy, safety education and green and sustainable chemistry in Sub-Sahara Africa.

Citation: Eronmhonsele, Job Imharobere, Erhabor Igbinosa Norris Ph.D. " Climate Change and the Economic Vulnerability of Household in Niger Delta Region" International Journal of Humanities Social Sciences and Education (IJHSSE), vol 8, no. 7, 2021, pp. 1-11. doi: https://doi.org/10.20431/2349. 0381.0807001 .

Copyright: () 2021 Authors. This is an open-access article distributed under the terms of the Creative Commons Attribution License, which permits unrestricted use, distribution, and reproduction in any medium, provided the original author and source are credited. 